\title{
Extension of oestrous cycles and prolonged secretion of progesterone in non-pregnant cattle infused continuously with oxytocin*
}

\author{
H. J. Howard†, D. E. Morbeck and J. H. Britt \\ Department of Animal Science, North Carolina State University, Raleigh, \\ North Carolina 27695-7621, USA
}

\begin{abstract}
Summary. The experimental objective was to evaluate how continuous infusion of oxytocin during the anticipated period of luteolysis in cattle would influence secretion of progesterone, oestradiol and 13,14-dihydro-15-keto-prostaglandin F-2 $\alpha$ (PGFM). In Exp. I, 6 non-lactating Holstein cows were infused with saline or oxytocin $(20 \mathrm{IU} / \mathrm{h}$, i.v.) from Day 13 to Day 20 of an oestrous cycle in a cross-over experimental design (Day $0=$ oestrus). During saline cycles, concentrations of progesterone decreased from $11.0 \pm 2.0 \mathrm{ng} / \mathrm{ml}$ on Day 14 to $2.0 \pm 1.3 \mathrm{ng} / \mathrm{ml}$ on Day 23 ; however, during oxytocin cycles, luteolysis was delayed and progesterone secretion remained near $11 \mathrm{ng} / \mathrm{ml}$ until after Day $22(P<0.05)$. Interoestrous interval was 1.6 days longer in oxytocin than in saline cycles $(P=0.07)$. Baseline PGFM and amplitude and frequency of PGFM peaks in blood samples collected hourly on Day 18 did not differ between saline and oxytocin cycles. In Exp. II, 7 non-lactating Holstein cows were infused with saline or oxytocin from Day 13 to Day 25 after oestrus in a cross-over experimental design. Secretion of progesterone decreased from $6.8 \pm 0.7 \mathrm{ng} / \mathrm{ml}$ on Day 16 to $<2 \mathrm{ng} / \mathrm{ml}$ on Day 22 of saline cycles; however, during oxytocin cycles, luteolysis did not occur until after Day $25(P<0.05)$. Interoestrous interval was 5.9 days longer for oxytocin than for saline cycles $(P<0.05)$. In blood samples taken every $2 \mathrm{~h}$ from Day 17 to Day 23, PGFM peak amplitude was higher $(P<0.05)$ in saline $(142 \cdot 1 \pm 25 \cdot 1 \mathrm{pg} / \mathrm{ml})$ than in oxytocin cycles $(109 \cdot 8 \pm 15 \cdot 2 \mathrm{pg} / \mathrm{ml})$. Nevertheless, pulsatile secretion of PGFM was detected during 6 of 7 oxytocin cycles. In both experiments, the anticipated rise in serum oestradiol concentrations before oestrus, around Days 18-20, was observed during saline cycles, but during oxytocin cycles, concentrations of oestradiol remained at basal levels until after oxytocin infusion was discontinued. We concluded that continuous infusion of oxytocin caused extended oestrous cycles, prolonged the secretion of progesterone, and reduced the amplitude of PGFM pulses. Moreover, when oxytocin was infused, pulsatile secretion of PGFM was not abolished, but oestrogen secretion did not increase until oxytocin infusion stopped.
\end{abstract}

Key'words: corpus luteum; prostaglandin; progesterone; oxytocin; cow

\section{Introduction}

Since the discovery that daily injections of oxytocin during the first week of the bovine oestrous cycle reduced duration of the cycle (Armstrong \& Hansel, 1959), several lines of evidence have

* Reprint requests to Dr J. H. Britt.

tPresent address: Reproduction Research Unit, USDA-ARS, Meat Animal Research Center, P.O. Box 166, Clay Center, NE 68933, USA. 
pointed to a role for oxytocin in regulating lifespan of the corpus luteum (CL; for a review in sheep, see McCracken et al., 1984), and it has now been shown that oxytocin is synthesized and secreted from the CL of cattle (Wathes et al., 1983) and sheep (Wathes et al., 1986). Flint \& Sheldrick (1983) noted that variation in peripheral concentrations of oxytocin paralleled the cyclic pattern of progesterone secretion and that the concentration of oxytocin was much greater in the ovarian or utero-ovarian vein than in the jugular vein, implicating the ovary as an important source of oxytocin during the oestrous cycle. During luteolysis, there is pulsatile release of prostaglandin (PG) F-2 $\alpha$ (Kindahl et al., 1976), and during the late luteal phase of sheep, approximately twothirds of pulses of PGF- $2 \alpha$ are associated with increases in oxytocin (Flint \& Sheldrick, 1983; Hooper et al., 1986). When exogenous oxytocin was given in the later part of the oestrous cycle of sheep (Fincher et al., 1986) or cattle (Lafrance \& Goff, 1985; Howard et al., 1990), an immediate increase in peripheral PGF-2 $\alpha$ was seen, and it is during this part of the cycle that endometrial receptors for oxytocin are highest (McCracken et al., 1984; Schams, 1987). During natural luteolysis, ovarian oxytocin and uterine PGF-2 $\alpha$ form a positive feedback loop that continues until the CL has completely regressed (Flint \& Sheldrick, 1986).

When sheep (Sheldrick et al., 1980; Schams et al., 1983; Wathes et al., 1989) or goats (Cooke \& Homeida, 1985) were actively immunized against oxytocin, oestrous cycles were lengthened and progesterone secretion was prolonged. In cyclic ewes, continuous infusion of oxytocin caused down-regulation of oxytocin receptors (Flint \& Sheldrick, 1985), and reduced release of PGF- $2 \alpha$ (Sheldrick \& Flint, 1987), leading to extended CL lifespan. In cattle, one study showed no effect of continuous oxytocin infusion on CL function (Kotwica et al., 1988), while another showed that progesterone secretion was prolonged when oxytocin was infused continuously (Gilbert et al., 1989); however, PGF-2 $\alpha$ was not measured in the study of Gilbert et al. (1989) during the time of luteolysis, so it is not clear whether oxytocin infusion altered the pattern of PGF-2 $\alpha$ secretion. Discrepancies therefore exist with regard to effects of continuous infusion of oxytocin on $\mathrm{CL}$ function and luteolysis in cattle, and little is known about how infusion of oxytocin influences PGF-2 $\alpha$ secretion. The objective of the present study was to determine whether continuous infusion of oxytocin prolonged CL function and decreased uterine PGF- $2 \alpha$ release in cattle.

\section{Materials and Methods}

General procedures. In each of 2 experiments, normally cycling, non-lactating Holstein cows had oestrous cycles synchronized by 2 injections of PGF-2 $\alpha$ (Lutalyse, Upjohn Co., Kalamazoo, MI, USA; $25 \mathrm{mg}$, i.m.), given 11 days apart. During the first synchronized cycle of each experiment, cows were given continuous infusion of saline or oxytocin, and when all cows had returned to oestrus, the cycles of these cows were re-synchronized and treatments were reversed in a cross-over experimental design. During periods when cows were infused continuously with oxytocin or saline, they were housed in a tie stall barn with water available ad libitum. A mixture of maize silage and grain concentrate was given to cows at 06:00 and 16:00 h each day. During the periods of infusion, cows were observed for oestrus for $30 \mathrm{~min}$ at $06: 00$ and 18:00 $\mathrm{h}$ on a grooved concrete lot $(4 \mathrm{~m} \times 28 \mathrm{~m})$.

Catheterization, blood collection and infusion. Catheters were inserted into right and left jugular veins of each cow, and blood was collected and processed according to the methods of Howard et al. (1990). Tubing of the same diameter as the catheters was suspended between a multichannel peristaltic pump (Cole-Parmer Instr. Co., Chicago, IL, USA) and each cow via 2 brass pulleys ( $20 \mathrm{~mm}$ diam.), one above the pump, and one above the shoulder of each cow. Enough slack remained in the infusion tubing to allow for rormal movements of cows, and lead weights $(30 \mathrm{~g})$ attached to the tubing between the infusion pump and pulleys maintained a small amount of tension to keep the slack in the catheters from being entangled. Infusion catheters remained connected at all times except when cows were turned out for detection of oestrus. Saline $(0.15 \mathrm{M}-\mathrm{NaCl})$ or oxytocin (diluted with saline to $2 \mathrm{IU} / \mathrm{ml}$; TechAmerica ${ }^{\circledR}$, Fermenta Animal Health Co., Kansas City, MO, USA) was infused at a rate of $10 \mathrm{~m} / \mathrm{h}$ so that each cow received $20 \mathrm{IU}$ oxytocin/h.

Experiment I. Six cows were infused with saline or oxytocin from Day 13 to Day 20 of each of 2 oestrous cycles. Blood samples were collected at 06:00,12:00, 18:00 and 24:00 h from Day 13 to Day 20 for determination of concentrations of progesterone, oestradiol and oxytocin. On Day 18 of each cycle, samples were collected every hour for $24 \mathrm{~h}$ for measurement of 13,14-dihydro-15-keto-prostaglandin F-2 $\alpha$ (PGFM) in serum. From Day 2 to Day 12, and from 
Day 21 until the onset of oestrus, blood samples were taken via the coccygeal vein daily or on alternate days for determination of progesterone and oestradiol concentrations in serum.

Experiment II. In Exp. I, the secretion of progesterone was prolonged by infusion of oxytocin without an apparent change in serum concentrations of PGFM on Day 18; therefore, during Exp. II cows were infused and samples collected for PGFM over a longer period. Seven cows were infused with saline or oxytocin from Day 13 to Day 25 in each of 2 cycles. Blood samples were collected at 06:00, 12:00, 18:00 and 24:00 h on Day 13 to Day 25 for determination of concentrations of progesterone, oestradiol and oxytocin. From Day 17 to Day 23 of each cycle, samples were collected every $2 \mathrm{~h}$ for concentration of PGFM. From Day 25 until the onset of oestrus, blood samples were taken daily via the coccygeal vein for determination of progesterone and oestradiol concentrations.

Analyses of hormones. The concentration of progesterone in serum was determined by procedures validated in this laboratory by Stevenson et al. (1981). The intra-assay and interassay coefficients of variation were 5.6 and $13.4 \%$, respectively, and the sensitivity of the assay was $0.2 \mathrm{ng} / \mathrm{ml}$.

Concentrations of oestradiol-17 $\beta$ were determined according to the procedures of Cox et al. (1987) as modified by Howard et al. (1990). Interassay and intra-assay coefficients of variation for the oestradiol assay were 11.2 and $15.5 \%$, respectively, and the sensitivity was $1.0 \mathrm{pg} / \mathrm{ml}$.

Concentrations of PGFM were determined by the procedures of Howard et al. (1990). Intra-assay and interassay coefficients of variation were 13.7 and $16.9 \%$, respectively, and the assay sensitivity was $30 \mathrm{pg} / \mathrm{ml}$.

Radioimmunoassay for oxytocin was as described by Gorewit (1979). Purified standards ( $>99 \%$ pure, $0.45 \mu \mathrm{U} / \mathrm{pg}$ ) and specific rabbit anti-oxytocin serum (Calbiochem/Behring Diagnostics, San Diego, CA, USA) were utilized. The intra-assay and interassay coefficients of variation were 8.5 and $8.6 \%$, respectively, and the assay sensitivity was $20 \mathrm{pg} / \mathrm{ml}$.

Statistical analyses. Data were analysed by least squares analysis of variance by using General Linear Models of the Statistical Analysis System (Spector et al., 1985). Data that contained repeated observations (e.g. hormone values) were analysed by methods of Gill \& Hafs (1971).

To characterize pulsatile secretion of PGFM, baseline values for individual cows were identified as nadir values between potential peaks of PGFM. An average baseline for a particular day was calculated, and peaks of PGFM were defined as maximum values that were greater than the baseline mean +2 s.d. Data were then summarized as baseline PGFM, PGFM peak amplitude, and PGFM peak frequency.

\section{Results}

\section{Experiment I}

The interoestrous interval of cycles during which oxytocin was infused was 1.6 days greater than for saline cycles $(P=0.07$, Table 1). During the period of infusion, oxytocin averaged $59 \pm 5 \mathrm{pg} / \mathrm{ml}$ in cows given saline compared with $522 \pm 29$ in those given oxytocin. Before the start of infusions, progesterone profiles were similar between saline and oxytocin cycles, increasing from 1-2 ng/ml on Day 2 to $10.7 \pm 1.3 \mathrm{ng} / \mathrm{ml}$ on Day 13 during both cycles (Fig. 1). Progesterone concentrations decreased to $<1 \mathrm{ng} / \mathrm{ml}$ on Day 25 in saline cycles, but during oxytocin cycles, progesterone remained near $10 \mathrm{ng} / \mathrm{ml}$ through Day 22 and then decreased to approximately $2 \mathrm{ng} / \mathrm{ml}$ by Day $26(P<0 \cdot 05)$.

Concentrations of oestradiol in serum increased during saline cycles from $2-3 \mathrm{pg} / \mathrm{ml}$ before Day 18 to $7 \cdot 2 \pm 1.9 \mathrm{pg} / \mathrm{ml}$ on Day 23 . In contrast, during oxytocin cycles, oestradiol concentrations did not start to increase until after infusions were terminated on Day 21 (Fig. $2 ; P<0.05$ ). Concentrations of oestradiol in serum continued to increase during the saline and oxytocin cycles until Day 24, which reflected the influence of 4 cows in each group that had interoestrous intervals of 23-25 days.

No differences in pulsatile PGFM were detected on Day 18 of saline and oxytocin cycles. Baseline PGFM, PGFM peak amplitude and peak frequency were similar between groups (Table 1).

\section{Experiment II}

Interoestrous intervals of cows infused with oxytocin were 5.9 days greater than those of cows infused with saline (Table $1 ; P<0.05$ ). During the period of infusion, oxytocin averaged $36 \pm 2 \mathrm{pg} / \mathrm{ml}$ in cows given saline compared with $678 \pm 14$ in those given oxytocin. Progesterone 
Table 1. Duration of oestrous cycles and characteristics of prostaglandin release of Holstein cows infused continuously with saline or oxytocin from Day 13 to Day 20 (Exp. I) or Day 13 to Day 25 (Exp. II) of the oestrous cycle

\begin{tabular}{|c|c|c|c|c|}
\hline Treatment & $\begin{array}{l}\text { Cycle length } \\
\text { (days) }\end{array}$ & $\begin{array}{l}\text { Baseline PGFM } \\
(\mathrm{pg} / \mathrm{ml})\end{array}$ & $\begin{array}{l}\text { Peak amplitude } \\
\quad(\mathrm{pg} / \mathrm{ml})\end{array}$ & $\begin{array}{l}\text { Peak frequency } \\
\text { (peaks } / 24 \mathrm{~h})\end{array}$ \\
\hline \multicolumn{5}{|c|}{ Experiment $\mathbf{I}^{\dagger}$} \\
\hline Saline & $23 \cdot 9 \pm 0 \cdot 6$ & $64 \cdot 1 \pm 6 \cdot 5$ & $43.4 \pm 6 \cdot 3$ & $4.0 \pm 0.9$ \\
\hline Oxytocin & $25.5 \pm 0.6^{*}$ & $70.9 \pm 6.0$ & $35.5 \pm 5.8$ & $4.5 \pm 0.8$ \\
\hline \multicolumn{5}{|c|}{ Experiment $\mathrm{II}_{+}^{+}$} \\
\hline Saline & $22.8 \pm 0.8$ & $73 \cdot 8 \pm 3 \cdot 7$ & $142 \cdot 1 \pm 25 \cdot 1$ & $2 \cdot 6 \pm 0 \cdot 2$ \\
\hline Oxytocin & $28.7 \pm 0.7^{* *}$ & $75.9 \pm 2.7$ & $109 \cdot 8 \pm 15 \cdot 2^{* *}$ & $2 \cdot 4 \pm 0 \cdot 2$ \\
\hline
\end{tabular}

*Values are mean \pm s.e.m.

*PGFM measured in samples taken every hour on Day 18 in Exp. I.

†PGFM measured in samples taken every $2 \mathrm{~h}$ on Day 17 in Exp. II.

${ }^{*} P<0.07$ compared with saline value.

**P $P<0.05$ compared with saline value.

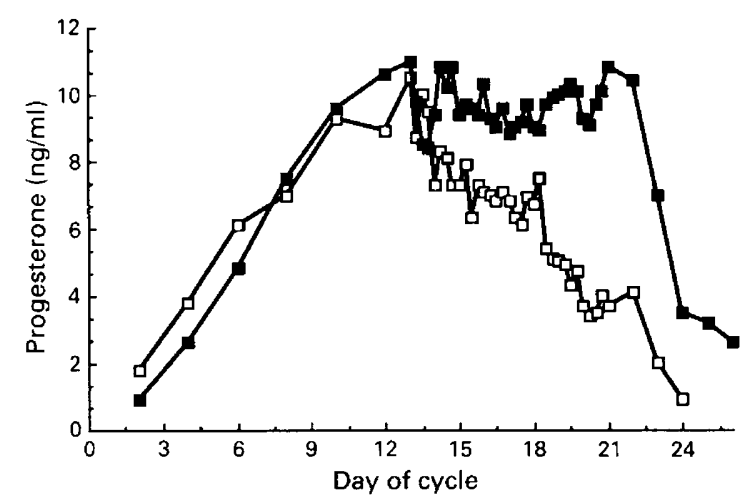

Fig. 1. Concentration of progesterone in serum of cows infused continuously with saline $(\square)$ or oxytocin ( $\square$ ) from Day 13 to Day 20 of the oestrous cycle. The pooled s.e. was $0 \cdot 3 \mathrm{ng} / \mathrm{ml}$.

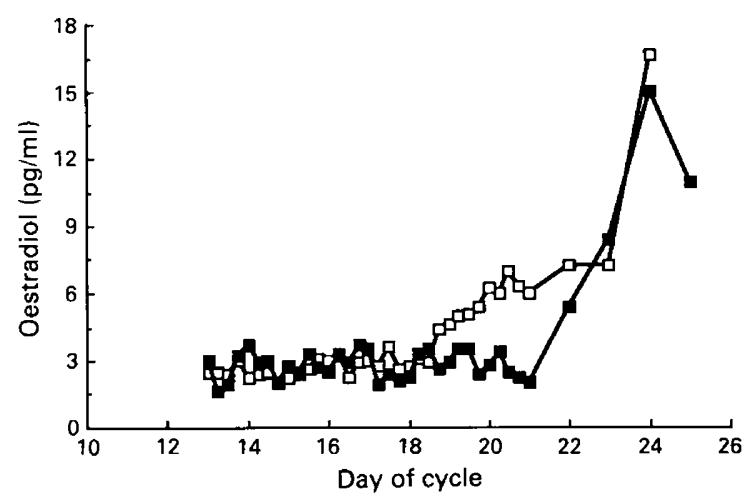

Fig. 2. Concentration of oestradiol in serum of cows infused continuously with saline $(\square)$ or oxytocin ( $\square$ ) from Day 13 to Day 20 of the oestrous cycle. The pooled s.e. was $0 \cdot 2 \mathrm{pg} / \mathrm{ml}$. 
concentrations were similar between groups from Day 13 to Day 16 (Fig. 3), but declined from $6.8 \pm 0.7 \mathrm{ng} / \mathrm{ml}$ on Day 16 to $<2 \mathrm{ng} / \mathrm{ml}$ by Day 20 of the saline cycles. In contrast, during oxytocin cycles, progesterone concentration remained at 6-7 ng/ml from Day 16 until Day 24, and was $>1 \mathrm{ng} / \mathrm{ml}$ until after Day $27(P<0.05)$.

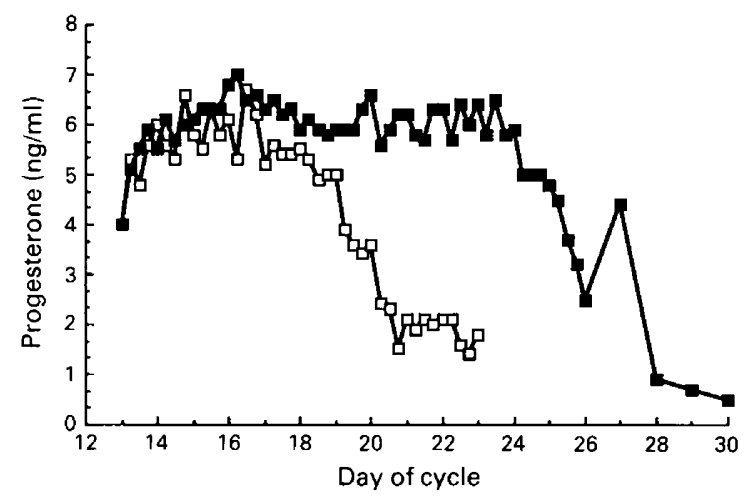

Fig. 3. Concentration of progesterone in serum of cows infused continuously with saline $(\square)$ or oxytocin ( $\boldsymbol{\square})$ from Day 13 to Day 25 of the oestrous cycle. The pooled s.e. was $0 \cdot 3 \mathrm{ng} / \mathrm{ml}$.

Serum oestradiol concentrations increased from $4.4 \pm 1.5 \mathrm{pg} / \mathrm{ml}$ on Day 20 to $8.4 \pm 3.5 \mathrm{pg} / \mathrm{ml}$ on Day 23 of saline cycles, but remained $<5 \mathrm{pg} / \mathrm{ml}$ until Day 25 of oxytocin cycles (Fig. 4). After withdrawal of oxytocin, concentration of oestradiol in serum rose sharply through Day 30 , when it reached $20 \cdot 1 \pm 3.0 \mathrm{pg} / \mathrm{ml}(P<0.05)$.

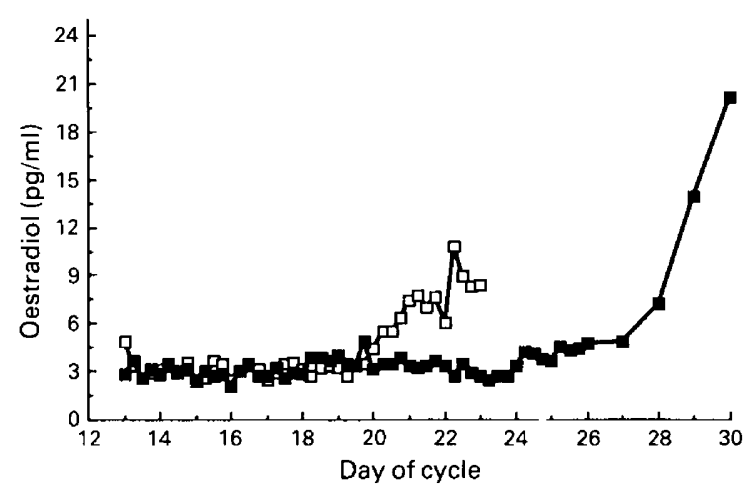

Fig. 4. Concentration of oestradiol in serum of cows infused continuously with saline $(\square)$ or oxytocin ( $\mathbf{\square})$ from Day 13 to Day 25 of the oestrous cycle. The pooled s.e. was $0 \cdot 2 \mathrm{pg} / \mathrm{ml}$.

Amplitude of PGFM peaks was greater during saline than oxytocin cycles (Table $1, P<0.05$ ), but peak frequency was similar between groups. Although amplitude of PGFM peaks was $32 \mathrm{pg} / \mathrm{ml}$ greater in saline than in oxytocin cycles, it was clearly evident that infusion of oxytocin did not completely abolish pulsatile release of PGFM, as evidenced by profiles of individual cows for each cycle (Fig. 5a-d). In all except one of the oxytocin cycles, there were periods of robust episodic secretion of PGFM, as well as periods of reduced peak amplitude. In the one cycle that was the exception, there were no discernible differences in patterns of episodic PGFM release between saline and oxytocin cycles. 
(Iu/bu) auodəəsə601d
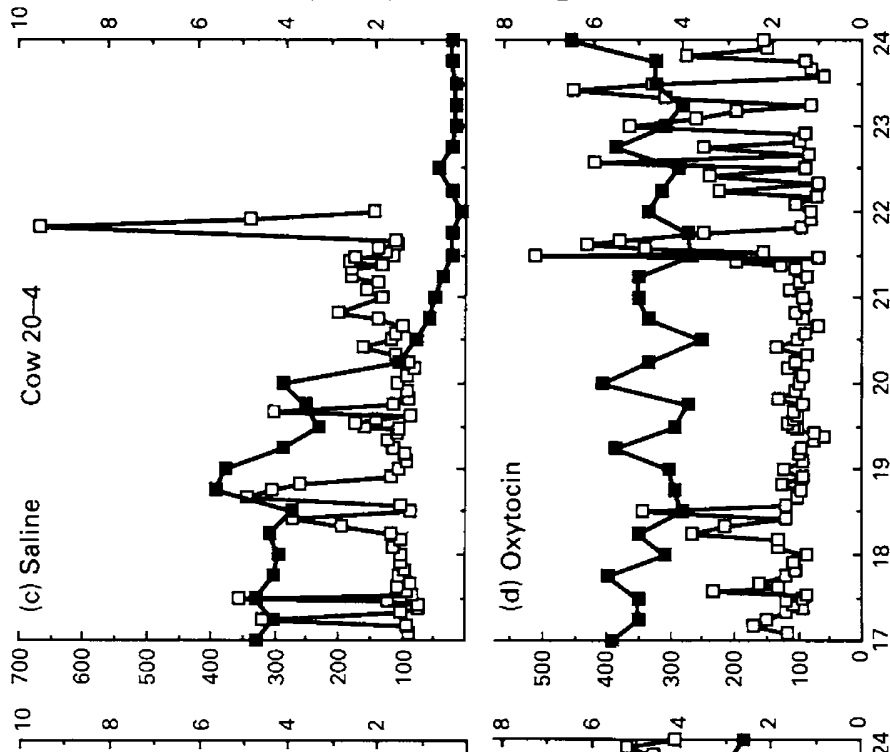
$\infty$

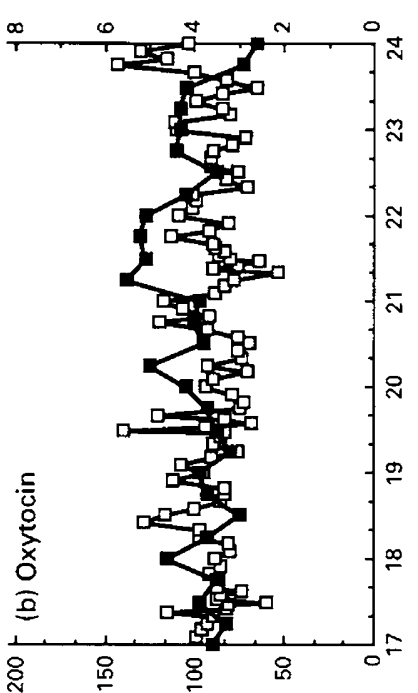

(jw/60) WADd

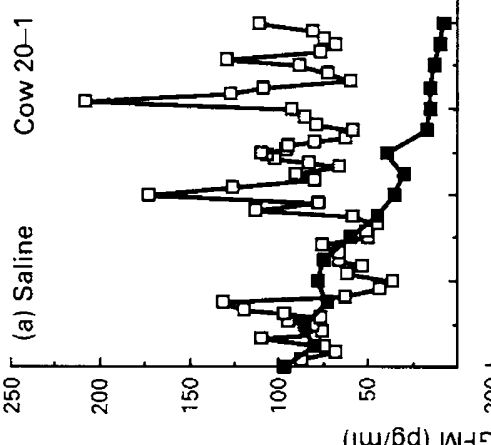




\section{Discussion}

In addition to the results of Flint \& Sheldrick (1985) in sheep, and those of Gilbert et al. (1989) in cattle, data from the present studies indicate that continuous intravenous infusion of oxytocin through the period of normal luteal regression causes extended oestrous cycles and prolonged secretion of progesterone. These results differ from those of Kotwica et al. (1988), who showed no changes in oestrous cycle lengths between control cycles and cycles of heifers infused continuously with oxytocin. Kotwica et al. (1988) did not present data concerning secretion of progesterone during control cycles, so comparisons between control and oxytocin-infused cycles regarding this could not be made.

Since the mechanism whereby continuous infusion of oxytocin extends CL lifespan is via downregulation of oxytocin receptors and reduced secretion of PGF-2 $\alpha$ (Flint \& Sheldrick, 1985; Sheldrick \& Flint, 1987), then PGFM should be drastically reduced. This might explain partially the reduction in PGFM pulse amplitude in oxytocin-infused cycles of the present study. However, the maintenance of progesterone secretion in the face of episodic PGFM remains unresolved. In the majority of cycles in which cows were infused with oxytocin, PGFM profiles were characterized by periods of robust pulsatile activity as well as times of secretory quiescence. Schramm et al. (1983) noted that, in sheep, 51 -h long infusions of PGF-2 $\alpha$ over a 24 -h period caused complete luteolysis, while 4 infusions did not. The dosages of PGF- $2 \alpha$ in that study were chosen to mimic changes in episodic release during luteolysis. If this were the case in cattle, then interruptions of episodic PGFM for short periods of time during oxytocin cycles of the present studies might have been adequate to delay luteolysis.

The time of the oestrous cycle that oxytocin infusion is started seems to be very critical. Kotwica et al. (1988) observed a large pulse of PGFM at the beginning of infusion on Days 14-16, suggesting that oxytocin receptors were already present in the uterus, and probably that episodic release of PGF- $2 \alpha$ was occurring. This would give a reasonable explanation for why secretion of progesterone was not prolonged in oxytocin-infused animals, since events leading to luteolysis were already set into motion. When infusions began on Day 10 (Gilbert et al., 1989), no pulse of PGFM was detected immediately after infusion was initiated, supporting the conclusion that uterine oxytocin receptors were in low concentrations on Day 10. It is unclear whether sufficient oxytocin receptors might have been present at the beginning of infusion in Exp. II to affect pulsatile PGFM release. During the normal ovine oestrous cycle, exogenous oxytocin caused release of uterine PGF-2 $\alpha$ as early as Day 13 of the cycle, although an increase in uterine oxytocin receptors was not seen until Day 15 (McCracken et al., 1984). Likewise in cattle, the first detectable increase in oxytocin receptors was seen on Day 15 (Schams, 1987), even though exogenous oxytocin as early as Day 14 caused an increase in concentrations of PGFM in serum (Howard et al., 1990). When ewes were infused continuously with oxytocin beginning on Day 13, oestrous cycles and secretion of progesterone were prolonged, and oxytocin receptor numbers were drastically down-regulated in uterine tissue collected on Day 17 (Flint \& Sheldrick, 1985). Therefore, presence or absence of oxytocin receptors at the beginning of oxytocin infusion in the present studies probably had little effect on whether or not down-regulation of oxytocin receptor numbers occurred. Regardless of what happened to oxytocin receptor number and PGFM secretion, progesterone secretion was still prolonged.

Part of the discrepancy between results of Kotwica et al. (1988) and others might have been caused by differences in dosage of oxytocin infused. Flint \& Sheldrick (1985) gave ewes $3 \mu \mathrm{g} / \mathrm{h}$, or about $144 \mu \mathrm{g} \cdot \mathrm{day}^{-1} \cdot(100 \mathrm{~kg} \text { body weight })^{-1}$. Gilbert et al. (1989) estimated that subcutaneous pumps placed in cattle delivered $26 \mu \mathrm{g} / \mathrm{h}$ at the start of infusion, and $9 \mu \mathrm{g} / \mathrm{h}$ near the end of infusion, corresponding to about 156 and $54 \mu \mathrm{g} \cdot \mathrm{day}^{-1} \cdot(100 \mathrm{~kg} \text { body weight })^{-1}$. Kotwica et al. (1988) gave heifers $12 \mu \mathrm{g} \cdot \mathrm{day}^{-1} \cdot(100 \mathrm{~kg} \text { body weight })^{-1}$, considerably lower than the doses in the studies of Flint \& Sheldrick (1985) and Gilbert et al. (1989). In the present study, the dosage of oxytocin was chosen to be similar to that used by Flint \& Sheldrick (1985). Highly purified oxytocin contains 
approximately $500 \mathrm{IU}$ oxytocin activity $/ \mathrm{mg}$, or $0.5 \mathrm{IU} / \mu \mathrm{gg}$. Ewes in their study were infused with $3 \mathrm{IU} \cdot \mathrm{h}^{-1} \cdot(100 \mathrm{~kg} \text { body weight })^{-1}$, slightly less than the $3 \cdot 33 \mathrm{IU} \cdot \mathrm{h}^{-1} \cdot(100 \mathrm{~kg} \text { body weight })^{-1}$ given to cows in the present experiment (average weight $=600 \mathrm{~kg}$ ).

Concentration of oxytocin in serum of cows in the present study reached $500-1000 \mathrm{pg} / \mathrm{ml}$ during oxytocin infusion, about a 25 -fold increase above pre-treatment and saline cycle concentrations of about $30-50 \mathrm{pg} / \mathrm{ml}$. This concentration was considerably higher than in other studies, in which oxytocin reached about $30 \mathrm{pg} / \mathrm{ml}$ in sheep (Flint \& Sheldrick, 1985), and about $30 \mathrm{pg} / \mathrm{ml}$ (Kotwica et al., 1988) to $90 \mathrm{pg} / \mathrm{ml}$ (Gilbert et al., 1989) in cattle, all above pre-treatment concentrations of $<10 \mathrm{pg} / \mathrm{ml}$. It is possible that differences in assay procedures could lead to some of the discrepancies in oxytocin concentrations, since preparations of oxytocin standards and antibody can vary widely. In addition, the procedure utilized in the present studies was with unextracted serum while others (Flint \& Sheldrick, 1985; Kotwica et al., 1988; Gilbert et al., 1989) used extracted sera. When oxytocin concentrations obtained in the present studies were converted from $\mathrm{pg} / \mathrm{ml}$ to $\mu \mathrm{U} / \mathrm{ml}$, baseline concentrations and assay sensitivity were very similar to those of studies in cattle in which the same assay protocol was used, including source of standard and antiserum (Gorewit, 1979; Wachs et al., 1984). Maintenance of physiological levels of oxytocin in the peripheral circulation was of concern in one study (Kotwica et al., 1988), although continuous infusion of oxytocin and resultant down-regulation of receptors should be considered a pharmacological, rather than a physiological effect. Heap et al. (1989) noted that, during the late luteal phase of sheep, infusion of physiological amounts of PGF- $2 \alpha$ into a uterine lymphatic vessel or uterine vein elicited increases in oxytocin to $>500 \mathrm{pg} / \mathrm{ml}$ in ovarian venous plasma and to $>1000 \mathrm{pg} / \mathrm{ml}$ oxytocin in utero-ovarian venous plasma. Endogenous peaks of oxytocin reach levels of $>1000 \mathrm{pg} / \mathrm{ml}$ in ovarian venous and utero-ovarian venous plasma in sheep as well (Hooper et al., 1986). Thus, while concentrations of oxytocin in the peripheral circulation of cows in the present study were well above the concentrations normally seen in jugular venous blood, concentrations achieved were in line with those seen in the ovarian or utero-ovarian blood supply under physiological conditions in sheep (Hooper et al., 1986; Heap et al., 1989).

In Exp. I, no differences were noted in the concentrations of PGFM in samples collected hourly on Day 18 of the cycle. This might not be surprising, since on Day 18 concentrations of progesterone in serum were still elevated during the saline and oxytocin cycles. Experiment II was conducted to evaluate more closely the influence of continuous infusion of oxytocin on PGFM secretion by taking blood samples over an extended period encompassing the normal time of luteolysis. In this experiment, secretion of PGFM was altered during cycles in which cows were infused with oxytocin, compared to cycles in which cows were given saline. There was a reduction in PGFM peak amplitude, without a reduction in peak frequency or baseline PGFM. Sheldrick \& Flint (1987) showed that ewes infused with oxytocin had reduced PGFM, with the majority of ewes having PGFM that remained at baseline concentrations, although there was episodic release of PGFM with reduced peak amplitude and frequency in some ewes. This was consistent with the results of the present study, since there was still episodic PGFM at certain times in the face of continuous oxytocin administration, with evidence of reduced peak amplitude in the majority of oxytocin cycles. In contrast to the present studies, Kotwica et al. (1988) indicated that PGFM in heifers infused with oxytocin was not interrupted when infusions were initiated on Day 14, 15 or 16 and continued through Day 19 or 21 , but they did not present data from control cycles, so direct comparisons between control and oxytocin cycles could not be made for PGFM.

Another effect of infused oxytocin may be on follicular development and secretion of oestradiol, since oestradiol remained at basal levels in oxytocin cycles until after infusion was terminated, when oestradiol increased abruptly. For both Exps I and II, there was only one cycle in which oestradiol increased before the end of oxytocin infusion. Since secretion of oestradiol is thought to be necessary to cause formation of oxytocin receptors on the endometrium (McCracken et al., 1984), attenuated PGFM may be attributed to a reduction in the release of follicular oestradiol. Oestradiol secretion may be necessary for PGF- $2 \alpha$ to cause complete luteolysis. For 
example, when heifers were given twice daily injections of low doses of oestradiol benzoate $(200 \mu \mathrm{g})$ from Days 10 to 12, or PGF-2 $\alpha$ ( $7 \mathrm{mg}$ ) on Day 12, none experienced luteolysis; however, when these low doses of oestradiol and PGF-2 $\alpha$ were given in sequence, complete luteolysis was induced (Hixon et al., 1983). In addition, when oestradiol secretion was reduced by cauterization of ovarian follicles and X-irradiation of ovaries (Villa-Godoy et al., 1985), or when the action of oestradiol was antagonized by the oestrogen antagonist, tamoxifen (Jacobs et al., 1988), secretion of progesterone and oestrous cycle length were extended. Hughes et al. (1987) showed that $15 \mathrm{mg}$ PGF-2 $\alpha$ caused complete luteolysis when given to control heifers on Day 14 of the cycle, but luteolysis did not occur when PGF-2 $\alpha$ was given on Day 14 to heifers whose follicles had been destroyed by cauterization and irradiation on Day 9 of the cycle. However, Flint \& Sheldrick (1985) gave a standard luteolytic dose $(125 \mu \mathrm{g})$ of cloprostenol, a synthetic analogue of PGF- $2 \alpha$, to ewes that were continuously infused with oxytocin, and complete luteolysis, and oestrus occurred. This indicated that, in oxytocin-infused ewes, oestradiol had no obligatory role in luteolysis, at least with the dose of PGF-2 $\alpha$ analogue used. In the present study, however, since progesterone secretion was maintained in oxytocin cycles in the face of pulsatile PGFM, there is a strong likelihood that the low endogenous oestradiol was inadequate to synergize with the endogenous PGF-2 $\alpha$ to bring about luteolysis.

In conclusion, infusion of oxytocin over the expected time of luteolysis during bovine oestrous cycles extended luteal function and oestrous cycles. This was primarily due to a reduction in the amplitude of PGFM pulses, but pulses were not abolished completely. The possibility also exists that endogenous PGF-2 $\alpha$ requires interactions with other endocrine factors, potentially oestradiol, to exert its full actions.

Paper No. 12451 of the Journal Series of the North Carolina Agricultural Research Service, Raleigh, N.C. 27695-7601. The use of trade names in this publication does not imply endorsement by the North Carolina Agricultural Research Service of the products named, or criticism of similar ones not mentioned. This research was supported in part by the North Carolina Dairy Foundation. We thank Vickie Hedgpeth for technical assistance; James Johnson and Chris Brown for care of the experimental animals; Dr N. R. Mason for antiserum to oestradiol; and Dr K. T. Kirton for antiserum to PGFM.

\section{References}

Armstrong, D.T. \& Hansel, W. (1959) Alteration of the bovine estrous cycle with oxytocin. J. Dairy Sci. 42, $533-542$.

Cooke, R.G. \& Homeida, A.M. (1985) Suppression of prostaglandin $\mathrm{F}-2 \alpha$ release and delay of luteolysis after active immunization against oxytocin in the goat. J. Reprod. Fert. 75, 63-68.

Cox, N.M., Ramirez, J.L., Matamoros, I.A., Bennett, W.A. \& Britt, J.H. (1987) Influence of season on estrous and luteinizing hormone responses to estradiol benzoate in ovariectomized sows. Theriogenology 27, 395-405.

Fincher, K.B., Bazer, F.W., Hansen, P.J., Thatcher, W.W. \& Roberts, R.M. (1986) Proteins secreted by the sheep conceptus suppress induction of uterine prostaglandin $\mathrm{F}-2 \alpha$ release by oestradiol and oxytocin. J. Reprod. Fert. 76, 425-433.

Flint, A.P.F. \& Sheldrick, E.L. (1983) Evidence for a systemic role for ovarian oxytocin in luteal regression in sheep. J. Reprod. Fert. 67, 215-225.

Flint, A.P.F. \& Sheldrick, E.L. (1985) Continuous infusion of oxytocin prevents induction of uterine oxytocin receptor and blocks luteal regression in cyclic ewes. J. Reprod. Fert. 75, 623-631.

Flint, A.P.F. \& Sheldrick, E.L. (1986) Ovarian oxytocin and the maternal recognition of pregnancy. $J$. Reprod. Fert. 76, 831-839.

Gilbert, C.L., Lamming, G.E., Parkinson, T.J., Flint, A.P.F. \& Wathes, D.C. (1989) Oxytocin infusion from day 10 after oestrus extends the luteal phase in non-pregnant cattle. J. Reprod. Fert. 86, 203-210.

Gill, J.L. \& Hafs, H.D. (1971) Analysis of repeated measurements of animals. J. Anim. Sci. 33, 331-336.

Gorewit, R.C. (1979) Method for determining oxytocin concentrations in unextracted sera; characterization in lactating cattle. Proc. Soc. exp. Biol. Med. 160, $80-87$.

Heap, R.B., Fleet, I.R., Davis, A.J., Goode, J.A., Hamon, M.H., Walters, D.E. \& Flint, A.P.F. (1989) Neurotransmitters and lymphatic-vascular transfer of prostaglandin $F 2 \alpha$ stimulate ovarian oxytocin output in sheep. J. Endocr. 122, 147-159.

Hixon, J.E., Pimental, C.A., Weston, P.G., Chafetz, E.P., Shanks, R.D. \& Hansel, W. (1983) A luteo- 
lytic interaction between estradiol benzoate and prostaglandin F2 $\alpha$ in cattle. J. Anim. Sci. 56, 1190-1197.

Hooper, S.B., Watkins, W.B. \& Thorburn, G.D. (1986) Oxytocin, oxytocin-associated neurophysin and prostaglandin $\mathrm{F}_{2 \alpha}$ concentration in the uteroovarian vein of pregnant and non-pregnant sheep. Endocrinology 119, 2590-2597.

Howard, H.J., Scott, R.G. \& J.H. Britt. (1990) Associations among progesterone, estradiol-17\%, oxytocin and prostaglandin in cattle treated with hCG during diestrus to extend corpus luteum function. Prostaglandins 40, 51-70.

Hughes, T.L., Villa-Godoy, A., Kesner, J. \& Fogwell, R.L. (1987) Destruction of bovine ovarian follicles: effects on the pulsatile release of luteinizing hormone and prostaglandin $F 2 \alpha$-induced luteal regression. Biol. Reprod. 36, 523-529.

Jacobs, A.L., Edgerton, L.A., Silvia, W.J. \& Schillo, K.K. (1988) Effect of an estrogen antagonist (tamoxifen) on cloprostenol-induced luteolysis in heifers. J. Anim. Sci. 66, 735-742.

Kindahl, H., Edqvist, L.-E., Granstrom, E. \& Bane, A. (1976) The release of prostaglandin $F 2 \alpha$ as reflected by 15-keto-13,14-dihydroprostaglandin $F 2 \alpha$ in the peripheral circulation during normal luteolysis in heifers. Prostaglandins 11, 871-878.

Kotwica, J., Schams, D., Meyer, H.H.D. \& Mettermeier, T.H. (1988) Effect of continuous infusion of oxytocin on length of the oestrous cycle and luteolysis in cattle. J. Reprod. Fert. 83, 287-294.

Lafrance, M. \& Goff, A.K. (1985) Effect of pregnancy on oxytocin induced release of prostaglandin $F_{2 a}$ in heifers. Biol. Reprod. 33, 1113-1119.

McCracken, J.A., Schramm, W. \& Okulicz, W.C. (1984) Hormone receptor control of pulsatile secretion of PGF $2 \alpha$ from the ovine uterus during luteolysis and its abrogation in early pregnancy. Anim. Reprod. Sci. $7,31-55$.

Schams, D. (1987) Luteal peptides and intercellular communication. J. Reprod. Fert. Suppl. 34, 87-99.

Schams, D., Prokopp, S. \& Barth, D. (1983) The effect of active and passive immunization against oxytocin on ovarian cycle in ewes. Acta endocr. Copenh. 103, $337-344$.
Schramm, W., Bovaird, L., Glew, M.E., Schramm, G. \& McCracken, J.A. (1983) Corpus luteum regression induced by ultra-low pulses of prostaglandin $\mathrm{F}-2 \alpha$. Prostaglandins 26, 347-364.

Sheldrick, E.L. \& Flint, A.P.F. (1987) Continuous infusion of oxytocin delays luteolysis in the ewe by reducing prostaglandin $\mathrm{F} 2 \alpha$ secretion. $J$. Reprod. Fert., Abstr. Ser. 1, 22.

Sheldrick, E.L., Mitchell, M.D. \& Flint, A.P.F. (1980) Delayed luteal regression in ewes immunized against oxytocin. J. Reprod. Fert. 59, 37-42.

Spector, P.C., Goodnight, J.H., Sall, J.P. \& Sarle, W.S. (1985) The GLM procedure. In SAS User's Guide: Statistics, pp. 433-506. SAS Institute Inc. Cary, NC.

Stevenson, J.S., Cox, N.M. \& Britt, J.H. (1981) Role of the ovary in controlling luteinizing hormone follicle stimulating hormone, and prolactin secretion during and after lactation in pigs. Biol. Reprod. 24, 341-343.

Villa-Godoy, A., Ireland, J.J., Wortman, J.A., Ames, N.K., Hughes, T.L. \& Fogwell, R.L. (1985) Effect of ovarian follicles on luteal regression in heifers. $J$. Anim. Sci. 60, 519-527.

Wachs, E.A., Gorewit, R.C. \& Currie, W.B. (1984) Oxytocin concentrations in response to milking stimuli through lactating and mammary involution. Dom. Anim. Endocrinol. 1, 141-154.

Wathes, D.C., Guldenaar, S.E.F., Swann, R.W., Webb, R., Porter, D.G. \& Pickering, B.T. (1986) A combined radioimmunoassay and immunocytochemical study of ovarian oxytocin production during the periovulatory period in the ewe. J. Reprod. Fert. 78, $167-183$.

Wathes, D.C., Swann, R.W., Birkett, S.D., Porter, G. \& Pickering, B.T. (1983) Characterization of oxytocin, vasopressin, and neurophysin from the bovine corpus luteum. Endocrinology 113, 693-698.

Wathes, D.C., Ayad, V.J., McGoff, S.A. \& Morgan, K.L. (1989) Effect of active immunization against oxytocin on gonadotrophin secretion and the establishment of pregnancy in the ewe. J. Reprod. Fert. 86, 653, 664.

Received 20 February 1990 